\title{
PENERAPAN E-LEARNING UNTUK MENUNJANG KEGIATAN BELAJAR MENGAJAR BAGI GURU DI LINGKUNGAN PCM KARTASURA
}

\section{Diah Priyawati \\ Informatika}

Universitas Muhammadiyah Surakarta

diah.priyawati@gmail.com

Naskah diterima 20 Juni 2020

Naskah direvisi 25 Juni 2020

Naskah diterima untuk publikasi 30 Juni 2020

\begin{abstract}
ABSTRAK
Perkembangan teknologi dan komunikasi mempengaruhi kemampuan berpikir dan kreatifitas siswa. Perubahan tersebut memberikan pengaruh untuk mengoreksi kekurangan dari pembelajaran konvensional, dimana proses belajar menggunakan papan tulis sebagai sarana utama, bersifat statis dan guru menjadi satu-satunya informasi. Selain itu, semakin banyak siswa yang harus ditangani guru dapat menurunkan kualitas mengajar. Pemanfaatan internet dalam proses belajar mengajar berupa e-learning mampu mengatasi kekurangan tersebut. Kegiatan pengabdian berupa pelatihan penggunaan e-learning bagi guru-guru di lingkungan PCM Kartasura bertujuan untuk meningkatkan kompetensi guru. Kegiatan ini diikuti sebanyak 21 peserta. Metode pelatihan berupa penyajian materi dan pendampingan penggunaan e-learning. Survei dilakukan kepada peserta sebelum pelaksanaan pelatihan (pretest) dan setelah pelaksanaan pelatihan (posttest). Hasil pengolahan data instrumen tes menunjukkan bahwa pengetahuan mengenai e-learning meningkat sebesar $12.38 \%$ dan kemampuan mengelola e-learning meningkat sebanyak $22.86 \%$ setelah pelaksanaan pengabdian.
\end{abstract}

KATA KUNCI : e-learning, media pembelajaran, pelatihan

\section{PENDAHULUAN}

Salah satu program kerja Muhammadiyah yaitu menghidupkan kembali dan merevitalisasi cabang dan rantingnya dalam upaya memperkuat dan memperteguh organisasi. Pimpinan Cabang Muhammadiyah (PCM) di Kartasura mempunyai tantangan dalam mengelola organisasi dan amal usaha, diantaranya memanfaatkan Ilmu Komunikasi dan Teknologi Informasi atau ICT (Information And Communication Technology) [1]. Kegiatan pengabdian ini difokuskan pada peningkatan kompetensi guru-guru di lingkungan PCM Kartasura.

Belajar adalah perubahan tingkah laku dan pemahaman, semula seorang anak tidak dibekali dengan potensi fitrah yang kemudian dengan belajar maka seorang anak berubah tingkah laku dan pemahamannya semakin bertambah [2]. Proses pembelajaran ditandai dengan adanya interaksi edukatif yang melibatkan beberapa komponen, dan guru harus mampu menggunakan komponen tersebut untuk mencapai tujuan yang direncanakan. Keberhasilan sistem pembelajaran sangat bergantung pada guru dalam menerapkan metode belajar, dan pencapaian tujuan. Evaluasi hasil belajar merupakan komponen yang digunakan untuk mengukur keberhasilan pembelajaran.

Pembelajaran secara konvensional saat ini kurang efektif. Kemampuan berpikir dan kreativitas siswa telah berkembang seiring dengan kemajuan teknologi dan komunikasi [3]. Perubahan tersebut memberikan pengaruh untuk mengoreksi kekurangan dari pembelajaran konvensional, dimana proses pembelajaran menggunakan papan tulis sebagai sarana utama, bersifat statis dan guru menjadi satu-satunya informasi. Selain itu, semakin banyak siswa yang harus ditangani guru dapat menurunkan kualitas mengajar. Pemanfaatan internet dalam proses pembelajaran seperti $e$ learning atau telekonferensi secara efisien mampu menutup kekurangan tersebut [4].

E-learning telah banyak meningkatkan kompetensi guru dalam melaksanakan proses pembelajaran [5][6][7]. Beberapa jenis e-learning yang dapat digunakan diantaranya adalah membangun website [5], moodle [8], Edmodo [3][9], media sosial seperti facebook, google drive, google form [6], dan google classroom [10]. Kendala yang dihadapi ketika menggunakan e-learning sendiri adalah budaya belajar mandiri siswa masih kurang, dan juga kemampuan guru dalam mendesain materi pelajaran belum berkembang [4]. Pemilihan e-learning yang popular dan mudah digunakan akan membantu guru menggunakan teknologi ini. Edmodo merupakan e-learning yang menyerupai facebook namun dikhususkan untuk kegiatan pendidikan [11]. Kegiatan pengabdian ini bertujuan untuk memberikan pengetahuan dan 
pelatihan penggunaan e-learning Edmodo bagi guru-guru di lingkungan PCM Kartasura.

\section{TINJAUAN PUSTAKA \\ E-learning}

E-learning merupakan proses pembelajaran dengan menggunakan perangkat elektronika, seperti komputer, gadget, atau alat pembelajaran elektronik lainnya [7]. E-learning memungkinkan siswa mendapatkan materi kapan saja, dipelajari dimanapun siswa berada. Guru dapat melakukan kegiatan belajar mengajar di kelas dan dilanjutkan pemantauan di luar kelas. Jumlah guru yang terbatas tetap dapat memberikan pengajaran yang berkualitas meskipun siswa bertambah banyak [4].

Cara penyampaian materi e-learning dilakukan secara satu arah atau dua arah. Cara satu arah seperti layaknya proses pembelajaran di kelas namun menggunakan perangkat elektronik. Cara dua arah adalah proses pembelajaran interaktif antara guru dan siswa menggunakan perangkat elektronik dalam waktu yang bersamaan (synchronous learning), atau dapat juga pada waktu yang tidak bersamaan (asynchronous learning) [4][7]. E-learning tidak memiliki batasan akses, sehingga proses belajar mengajar dapat dilakukan lebih banyak waktu.

\section{Edmodo}

Edmodo adalah sebuah platform media sosial seperti facebook namun diterapkan untuk lingkungan sekolah. Guru dan siswa saling berinteraksi seperti layaknya menggunakan facebook membahas hal-hal seputar kegiatan belajar mengajar [11]. Penyimpanan data Edmodo dilakukan melalui jaringan internet yang aman atau cloud storage.

Fasilitas-fasilitas yang ditawarkan Edmodo yaitu : (1) aplikasi Edmodo gratis, dan hanya diperlukan jaringan internet untuk menggunakannya. (2) Guru dapat memberikan materi secara tidak langsung kepada siswa, dan siswa dapat belajar kapan saja. (3) Guru dapat menilai tugas siswa dan siswa dapat memantau hasil pekerjaannya. (4) Guru dan siswa dapat saling berinteraksi mengemukakan pendapatnya mengenai permasalah sebuah topik. (5) Edmodo menyediakan berberapa teknik pembuatan soal secara daring, seperti soal pilihan ganda, esai, mengurutkan, mencocokkan, melengkapi bagianbagian soal yang kosong, hingga melakukan pooling. (6) Edmodo dapat diakses melalui gadget sehingga sangat sesuai dengan kondisi perkembangan teknologi saat ini [9][11].

\section{METODE}

Metode yang digunakan dalam kegiatan pengabdian ini adalah model pendampingan penggunaan Edmodo dalam menyusun materi pelajaran sekolah yang terbagi dalam dua tahap. Tahap pertama yaitu penyajian materi pengenalan Edmodo, menyusun materi ajar yang sesuai dengan sistem e-learning, membuat alat evaluasi belajar berbasis e-learning, hingga proses menggunggah ke dalam aplikasi Edmodo. Tahap kedua, peserta pelatihan saling memberikan saran kritik terhadap e-learning yang telah dibuat, dan diakhiri dengan cara menambahkan pengguna (member) Edmodo yaitu para siswanya.

Kegiatan pengabdian dievaluasi dengan pengambilan instrumen tes kepada peserta sebelum pelaksanaan pelatihan (pretest) dan setelah pelaksanaan pelatihan (posttest).

\section{HASIL DAN PEMBAHASAN \\ Hasil}

Kegiatan pengabdian berupa pelatihan ini berjudul Aplikasi e-learning untuk Menunjang Kegiatan Belajar Mengajar bagi Guru di PCM Kartasura. Kegiatan dilaksanakan pada tanggal 3 Februari 2017 bertempat di Laboratorium Sistem Informasi, Program Studi Informatika, Fakultas Komunikasi dan Informatika, Universitas Muhammadiyah Surakarta. Peserta kegiatan sebanyak 21 orang meliputi guru-guru sekolah di wilayah PCM Kartasura seperti ditunjukkan pada Tabel 1. Kegiatan pengabdian ini merupakan bagian dari rangkaian Pelatihan Media dan Aplikasi Teknologi Informasi Bagi Guru di Pimpinan Cabang Muhammadiyah Kartasura pada tanggal $3-5$ Februari 2017.

Table 1. Daftar Peserta Pelatihan

\begin{tabular}{lc}
\hline \multicolumn{1}{c}{ Sekolah } & Jumlah Delegasi \\
\hline MI Muh Gonilan & 2 \\
MI Muh Kartasura & 2 \\
MI Muh Kertonatan & 1 \\
MI Muh Wirogunan & 1 \\
MI Muh Pucangan & 2 \\
SDIT Muh Al Kautsar & 3 \\
SMP Muh 1 Kartasura & 2 \\
SMP Muh 2 Kartasura & 2 \\
SMP Muh Al Kautsar & 2 \\
PK & 2 \\
SMK Muh Kartasura & 2 \\
SMA Muh 4 Kartasura & 21 \\
\hline Total Delegasi & \\
\hline
\end{tabular}


Kegiatan terbagi menjadi tiga tahapan. Tahap pertama, pengambilan instrumen tes sebelum dilakukan pelatihan (pretest). Tahap kedua, penyajian materi pengenalan e-learning Edmodo melalui ceramah. Selanjutnya peserta mengikuti instruksi dengan praktek langsung menggunakan Edmodo, diakhiri dengan sesi tanya jawab. Gambar 1 menunjukkan kondisi kegiatan pelatihan dimana peserta pelatihan mengenal dan menggunakan Edmodo. Tahap ketiga adalah pengambilan instrumen tes setelah dilakukan pelatihan (posttest).

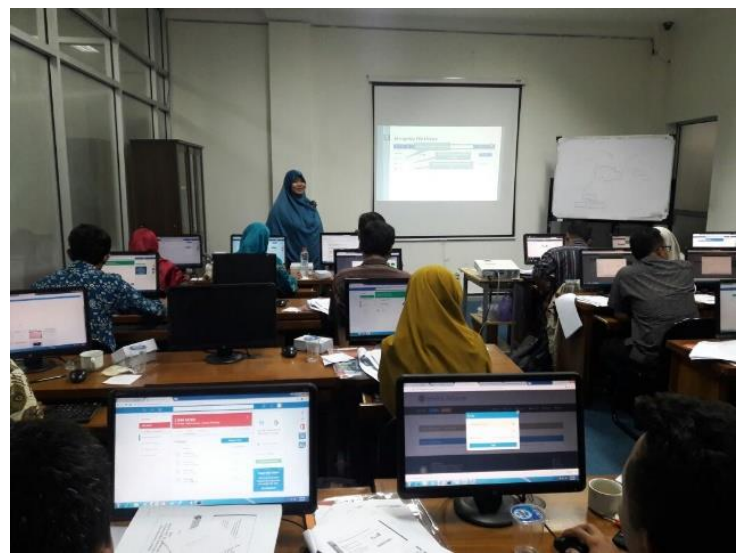

Gambar 1. Suasana pelatihan

\section{Pembahasan}

Tujuan pengambilan pretest adalah untuk mengetahui sejauh mana pengetahuan seputar materi. Peserta memberi pendapat mengenai permasalahan yang ditanyakan seperti pada Tabel 1. Data hasil instrumen tes diolah menggunakan skala Likert. Skala Likert digunakan untuk mengukur persepsi atau pendapat seseorang mengenai peristiwa karena mampu mengetahui tingkat kepastian dalam sebuah survei [12]. Hasil survei pretest ditunjukkan pada Tabel 2.

Table 1. Pertanyaan instrumen tes

\begin{tabular}{cl}
\hline No & \multicolumn{1}{c}{ Pertanyaan } \\
\hline 1 & Saya mengenal internet \\
2 & Sehari-hari saya terbiasa menggunakan internet \\
3 & Saya mengenal surel \\
4 & Saya terbiasa menggunakan surel \\
5 & Saya tahu peran teknologi informasi untuk \\
& pendidikan \\
6 & Saya mengenal e-learning \\
8 & Saya terbiasa menggunakan e-learning \\
\hline
\end{tabular}

Selanjutnya pelatihan dimulai dengan mengenalkan peserta dengan e-learning Edmodo, memperlihatkan kemampuan yang dapat dibuat menggunakan aplikasi ini. Peserta mendaftarkan diri sebagai instruktur/guru pada aplikasi Edmodo. Sehingga dapat menggunakan fasilitas Edmodo secara lengkap. Kegiatan pelatihan dilakukan dengan metode pendampingan, dan peserta mencoba praktek secara langsung sesuai dengan arahan pemateri.

Table 2. Hasil survei pretest

\begin{tabular}{lc}
\hline \multicolumn{1}{c}{ Indikator } & Skor \\
\hline Mengenal internet & $90.48 \%$ \\
Terbiasa menggunakan internet & $86.67 \%$ \\
Mengenal surel & $87.62 \%$ \\
Terbiasa menggunakan surel & $83.81 \%$ \\
Mengetahui peran teknologi & $85.71 \%$ \\
$\quad$ informasi untuk pendidikan & \\
Mengenal e-learning & $67.62 \%$ \\
Terbiasa menggunakan e-learning & $57.14 \%$ \\
Mampu mengelola e-learning & $53.33 \%$ \\
\hline
\end{tabular}

Kegiatan pelatihan diakhiri dengan pengisian posttest untuk mengetahui keberhasilan capaian kegiatan. Tabel 3 merupakan hasil survei posttest.

\begin{tabular}{lc}
\multicolumn{2}{c}{ Table 3. Hasil survei posttest } \\
\hline \multicolumn{1}{c}{ Indikator } & Skor \\
\hline Mengenal internet & $93.33 \%$ \\
Terbiasa menggunakan internet & $91.43 \%$ \\
Mengenal surel & $92.38 \%$ \\
Terbiasa menggunakan surel & $86.67 \%$ \\
Mengetahui peran teknologi & $89.52 \%$ \\
\multicolumn{2}{c}{ informasi untuk pendidikan } \\
Mengenal e-learning \\
Terbiasa menggunakan e-learning \\
Mampu mengelola e-learning \\
\hline
\end{tabular}

Hasil pengolahan survei pretest dan posttest memperlihatkan bahwa pengetahuan dan kemampuan peserta meningkat setelah melalui kegiatan pengabdian ini. Peserta mengenal $e$ learning meningkat dari $67.62 \%$ menjadi $80 \%$. Peserta mampu mengelola e-learning meningkat dari $53.33 \%$ menjadi $76.19 \%$.

\section{KESIMPULAN DAN SARAN Kesimpulan}

Kegiatan pengabdian kepada masyarakat dalam bentuk pelatihan penggunaan e-learning telah berjalan baik. Kegiatan menghasilkan beberapa materi ajar yang siap digunakan untuk sistem pembelajaran secara daring. Hasil pengolahan data instrumen tes menunjukkan bahwa pengetahuan mengenai e-learning meningkat sebesar $12.38 \%$ dan 
kemampuan mengelola e-learning meningkat sebanyak $22.86 \%$.

\section{Saran}

Media pembelajaran sebaik apapun tidak dapat menggantikan peran guru sebagai pendidik. Elearning merupakan alat untuk menambah wawasan peran teknologi bagi pendidikan. Penggunaan e-learning harus menyenangkan, dan tetap menjunjung norma-norma kehidupan.

\section{PERSANTUNAN}

Ucapan terima kasih ditujukan untuk Fakultas IImu Komunikasi dan Informatika UMS, Laboratorium Program Studi Informatika UMS, Pimpinan Cabang Muhammadiyah Kartasura Sukoharjo, dan seluruh peserta pelatihan.

\section{DAFTAR PUSTAKA}

[1] "Lembaga Pengembangan Cabang dan Ranting | Muhammadiyah." http://Ipcr.muhammadiyah.or.id/ (accessed Jun. 14, 2020).

[2] A. Pane and M. Darwis Dasopang, "Belajar Dan Pembelajaran," FITRAHJurnal Kaji. IImuilmu Keislam., vol. 3, no. 2, p. 333, 2017, doi: 10.24952/fitrah.v3i2.945.

[3] M. Islamiyah and L. Widayanti, "Efektifitas Pemanfaatan E-learning Berbasis Website Terhadap Hasil Belajar Mahasiswa STMIK Asia Malang Pada Mata Kuliah Fisika Dasar," J. IIm. Teknol. Inf. Asia, vol. 10, no. 1, pp. 41-46, 2016, doi: ISSN: 0852-730X.

[4] S. Waluyanti, "Implementasi e-learning dalam pengembangan pendidikan dan pelatihan," pp. 1-12, 2015.

[5] I. Sriyanti, M. Muslim, and M. Yusup, "Pelatihan Pembuatan Media Pembelajaran Berbasis E-Learninng Bagi Guru SMA Srijaya Negara Palembang," J. Inov. dan Pembelajaran Fis., vol. 2, no. 1, pp. 12-18, 2015.

[6] D. Setiawan, S. Lestari, D. S. Putra, and M. Azmi, "Pemanfaatan Media Sosial untuk Membangun Sistem E-learning di SMKN 1 Gunung Talang," INVOTEK J. Inov. Vokasional dan Teknol., vol. 18, no. 1, pp.
7-12,

2018,

doi:

10.24036/invotek.v18i1.177.

[7] A. Ranius, "Pemanfaatan E-learning Sebagai Media Pembelajaran," J. IIm. Matrik, no. 12, pp. 53-62, 2013.

[8] R. H. Hardyanto and H. D. Surjono, "Pengembangan Dan Implementasi $E$ learning Menggunakan Moodle Dan Vicon Untuk Pelajaran Pemrograman Web Di Smk," J. Pendidik. Vokasi, vol. 6, no. 1, p. 43, 2016, doi: 10.21831/jpv.v6i1.6675.

[9] A. Z. Nu'man, “Efektifitas Penerapan Elearning Model Edmodo Dalam Pembelajaran Pendidikan Agama Islam Terhadap Hasil Belajar Siswa (Studi Kasus: Smk Muhammadiyah 1 Sukoharjo)," J. Chem. Inf. Model., vol. 53, no. 9, pp. 16891699, 2013, doi: 10.1017/СВ09781107415324.004.

[10] I. Yustanti and D. Novita, "Pemanfaatan Elearning Bagi Para Pendidik Di Era Digital 4. 0," Pros. Semin. Nas., pp. 338-346, 2019, [Online]. Available: https://jurnal.univpgripalembang.ac.id/index.php/Prosidingpps/ar ticle/download/2543/2357.

[11] N. Borg and J. O'Hara, "The Edmodo Teacher Guide," Soc. Learn. Netw. Classr., 2008.

[12] T. Nempung, T. Setiyaningsih, and N. Syamsiah, "Otomatisasi Metode Penelitian Skala Likert Berbasis Web," no. November, pp. 1-8, 2015 